\title{
TAXATION OF MISAPPROPRIATED PROPERTY: THE DECLINE AND INCOMPLETE FALL OF WILCOX*
}

The definition of taxable income in Section 22(a) of the Internal Revenue Code draws no distinction between lawful and unlawful gains. ${ }^{1}$ Profits of illegal businesses, such as bootlegging and bookmaking, and proceeds of unlawful transactions, such as bribes, have always been taxed. ${ }^{2}$ However, the

*Rutkin v. United States, 343 U.S. 130 (1952).

1. The Income Tax Act of 1913, §IIB, 38 StaT. 167 (1913), taxed, among other things, "gains, profits, and income derived from . . . the transaction of any lazufil business" (emphasis added). The word "lawful" has been absent since the Income Tax Act of 1916, §2(a), 39 STAт. 757 (1916). On the basis of this omission, courts have inferred that Congress intended to tax illegal, as well as legal, gains. E.g., Rutkin v. United States, 343 U.S. 130, 138 (1952) ; United States v. Sullivan, 274 U.S. 259, 263 (1927). Sec Com* missioner v. Wilcox, 327 U.S. 404, 411 (1946) (dissenting opinion). On the taxability of illegal income generally, see 1 Mertens, The Law of Federal. Income Taxatron $\$ 4.11$ (1942, Supp. 1952); Geller \& Rogers, How the Federal Incone Tax Applies to Illegal and Unlazeful Gains, 27 TAxes 214 (1949).

The privilege against self-incrimination does not excuse the failure to report illegal income. United States v. Sullivan, 274 U.S. 259, 264 (1927). But the Burcat of Internal Revenue has permitted criminals to report income in round numbers with non-incriminating designations as to source, such as "gambling gains" or "other income." SEN. REx. No. 141, 82d Cong., 1st Sess. 31-2 (1951). This policy has been severely criticized as conducive to tax evasion and thus unfair to honest taxpayers, particularly to corporations (which are required to keep detailed records). See, c.g., 98 Cong. Rec. 6128-30 (May 27, 1952); Baker, Taxation: Potential Destroyer of Crime, 29 Cnr-Kent Rev. 197, 217 (1951). Recently, legislation was proposed which would require more specific disclosure of income sources, but the bill died in committee. H.R. 7893, 82d Cong., 2d Sess. (1952). See generally Meltzer, Required Records, The McCarran Act, and the Privilege Against Self-Incrinination, 18 U. of CHI. L. REv. 687, 708-19 (1951).

2. Illegal businesses: United States v. Sullivan, 274 U.S. 259 (1927) (bootlegging); United States v. Chapman, 168 F.2d 997 (7th Cir.), cert. denied, 335 U.S. 853 (1948) (black market in meat packing); Barker v. Magruder, 95 F.2d 122 (D.C. Cir. 1938) (usurious loans); Steinberg v. United States, 14 F.2d 564 (2d Cir. 1926) (bootlegging); James P. McKenna, 1 B.T.A. 326 (1925) (bookmaking); Wallace H. Petit, 10 T.C. 1253 (1948) (black market profits of wholesale grocery); George L. Rickard, 15 B.T.A. 316 (1929) (prize-fight movies illegally transported in interstate commerce). Sec also Mary Luginbuhl, 8 T.C.M. 968 (1949) (taxability of abortionist's income not challenged).

Unlawful transactions: Caldwell v. Commissioner, 135 F.2d 488 (5th Cir. 1943) ("kickbacks" from contractors); Chadick v. United States, 77 F.2d 961 (5th Cir. 1935) (graft) ; Patterson v. Anderson, 20 F. Supp. 799 (S.D.N.Y. 1937) (illegal insurance contract) ; L. Weiner, 10 B.T.A. 905 (1928) (poker winnings); A. L. Voyer, 4 B.T.A. 1192 (1926) (lottery winnings). See also Johnson v. United States, 318 U.S. 189 (1943) ("protection" payments).

Income unlawfully received from a corporation, such as dividends, bonuses, and salaries, paid in violation of the rights of stockholders or creditors, is taxable. See Comment, 58 Y ALE L.J. 955, 960 n.26 (1949). 
tax status of wrongful appropriations has been less certain. ${ }^{3}$ Early dicta in the Second Circuit indicated that proceeds of embezzlement, robbery, and burglary were not taxable.* But subsequent development of the "claim of right" doctrine, indicating that funds were taxable to the recipient when he treated them as his own, even if he lacked a legal right to them, ${ }^{5}$ caused the Second Circuit to repudiate its dicta. ${ }^{\circ}$ Ransom money was later taxed in the year of receipt by the Seventh Circuit ; embezzled funds, by the Eighth Cir-

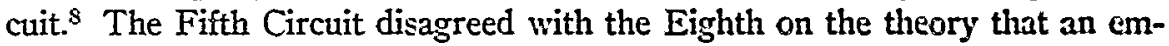
bezzler lacks any "color of right" to his loot and is under an immediate legal duty to repay it. ${ }^{9}$

The Supreme Court later followed the view of the Fifth Circuit. In the now famous IVilcox case, ${ }^{10}$ the Court held an embezzler immune from taxation in the year of embezzlement on the ground that he then lacks a "claim of right" to, and is under a "definite, unconditional obligation to repay," the misappropriated funds ${ }^{11}$-although the Court indicated, in dicta, that the "cancellation or retirement" of the "unconditional" indebtedness might produce taxable income. ${ }^{12}$ Clearly, the Court departed from the previous inter-

3. See Geller \& Rogers, Embczalement Has Its Tax Problcns, Too, 26 TAxes 1097 (1978).

4. See Rau v. United States, 260 Fed. 131, 136 (2d Cir. 1919); Steinberg v. United States, 14 F.2d 564, 566 (2d Cir. 1926).

5. The "claim of right" doctrine was adopted by the Supreme Court in North American Oil Consolidated v. Burnet, 286 U.S. 417 (1932). But this decision did not malse clear whether "claim of right" referred to the taxpayer's legal right to receipts or merely to his treatment of the receipts as his own. Subsequent eases generally used "elaim of right" in the latter sense. See note 13 infro.

6. National City Bank v. Helvering, 98 F.2d 93, 96 (2d Cir. 1938).

7. Humphreys v. Commissioner, 125 F.2d 340 (7th Cir. 1942).

8. Kurrle v. Helvering, 126 F.2d 723 (Sth Cir. 1942). The Treasury Department had previously taken this stand. G.C.M. 16572, XV-1 Cus. BuLl. 82 (1936).

9. Micknight v. Commissioner, 127 F.2d 572 (5th Cir. 1942). The duty to repsy is normally not imposed on the taspayers in the cases cited in note 2 supro, since they generally acquired money, not from innocent victims, but from willing participants in illegal activity. Since these participants stand in pari delicto with the recipients, they cannot seek recovery. However, several state statutes allow recuvery of gambling lozses. E.g., 3 Conn. Gen. Stat. \$6786 (1949); N.Y. Penal Law \$995. Some have speculated that such statutes might preclude the taxability of gambling gains. Baker, Tasufion: Potential Destroyer of Crime, 29 Chi-Kent Rev. 197, $207-09$ (1951); Note, 34 Chlir. L. REv. 449, 450 (1946). But this possibility has been definitely removed. Ruthin v. United States, 343 U.S. 130 (1952).

10. Commissioner v. Wilcos, 327 U.S. 404 (1946); noted, inter alia, 34 Cunr. L. Rev. 449 (1946) ; 22 IND. L.J. 99 (1946); 25 TEx. L. REv. 693 (1947). The case is also discussed in Geller \& Rogers, Embezalenent Has Its Tax Problens, Too, 26 Taxes 1097, 1100 (1948); Comment, 58 YaLe LoJ. 955, 962-3 (1949).

11. 327 U.S. at 408.

12. Ibid. See note 37 infra. The Court also declared that tavable incume might arise if the wrongdoer earned profits on the embezzled funds. Cf. United States v. Iozia, 104 F. Supp. $\$ 46$ (S.D.N.Y. 1952) (receipts from sale of converted goods taised). 
pretation of "claim of right." A taxpayer who treated funds as his own had been regarded as having a "claim of right" and thus was the recipient of taxable income, even though he might later be forced to repay. ${ }^{13}$ Wilco.t ignored the taxpayer's treatment of the funds and equated "claim of right" with a "bona fide legal or equitable claim."14 The Court did not define the latter phrase, but it seems reasonable to assume-if good faith means anythingthat all wrongdoers who take from innocent parties would lack a "claim of right."15 However, by also failing to define "unconditional obligation," the Court left its criteria of taxability in doubt. Misappropriators who acquire title to property might be taxed, since the obligation to repay is theoretically contingent on the rightful owner's first voiding the title. ${ }^{10}$ But a broader interpretation of "unconditional" would exempt all misappropriators from taxation in the year of receipt, whether or not they acquired title. ${ }^{17}$

13. National City Bank v. Helvering, 98 F.2d 93, 96 (2d Cir. 1938) (executive taxed on misappropriated corporate income) ; Penn v. Robertson, 115 F.2d 167 (4th Cir. 1940) (dividends taxable to recipient, although paid under stock allotment plan declared to be void $a b$ initio); United States v. Wampler, 5 F. Supp. 796 (D. Md. 1934) (attorney taxed on funds misappropriated from client). See Commissioner v. Wilcox, 327 U.S. 404, 410 (1946) (dissenting opinion). But cf. Commissioner v. Turney, 82 F.2d 661 (5th Cir. 1936) (part of oil royalties owed to Texas under state statute held not taxable even though taxpayer apparently had no intention of paying the state), criticized in National City Bank v. Helvering, supra. See, generally, Comment, 58 Yale L.J. 955 (1949).

An agent is obligated to turn over to his principal any gains, however illicit, such as bribes, that he receives by virtue of his employment. 2 Restatentent, AGencr $\$ \$ 388$, 403 (1933) ; Restatenent, Restitution $\$ 197$ (1937). This rule, however, has not deterred courts from levying a tax on agents for such income. Caldwell v. Commissioner, 135 F.2d 488 (5th Cir. 1943) ("kickbacks"). See also post-Wilcox cases: United States v. Chapman, 168 F.2d 997 (7th Cir.), cert. denied, 335 U.S. 853 (1948) (black market premiums); Wallace H. Petit, 10 T.C. 1253 (1948) (same).

14. "Without some bona fide legal or equitable claim, even though it be contingent or contested in nature, the taxpayer cannot be said to have received any gain or profit within the reach of $\$ 22$ (a)." Commissioner v. Wilcox, 327 U.S. 404, 408 (1946).

15. See United States v. Rutkin, 189 F.2d 431 (3d Cir. 1951), aff'd (using different rationale), 343 U.S. 130 (1952) (extorted funds held taxable). Two judges in the Court of Appeals found that by virtue of past business dealings with his victim, the extortioner had a "semblance of a bona fide claim of right." 189 F.2d at 435 . One judge dissented, inter alia, on the basis of the extortioner's obvious "bad faith." Id. at 442 . Four justices of the Supreme Court agreed. 343 U.S. at 139. By contrast, courts have applied the $\mathrm{W} i /$ cox "good faith" standard to tax those who receive income as the result of an innocent mistake of fact, believing it to be rightfully theirs, and repay it promptly upon discovery of the error. United States v. Lewis, 340 U.S. 590 (1951) (improperly computed bonus); Haberkorn v. United States, 173 F.2d 587 (6th Cir. 1949) (same). Thus, paradoxically, "good faith" incurs tax liability while "bad faith" may avoid it.

16. Restatenrent, Restitution $\$ \S 64,144$ (1937). At one point, Wilco.x calls attention to the fact that "All right, title and interest in the [embezzled] money rested with the employer." Commissioner v. Wilcox, 327 U.S. 404, 409 (1946) (emphasis added). Sec also Akers v. Scofield, 167 F.2d 718 (5th Cir.), cert. denied, 335 U.S. 823 (1948). And see 44 Micri. L. REv. 885 (1946). 
The ambiguity implicit in "unconditional obligation to repay" thus left unclear what wrongful appropriations would escape taxation upon receipt. If the absence of title fulfills this requirement, only the loot of embezzlers and thieves would be tax exempt. Such wrongdoers are held to lack title because they take the property without the rightful owner's consent. ${ }^{18}$ Swindlers and extortioners, however, would be taxed. Under prevailing doctrine, they acquire title because their victims, although deceived or coerced, deliver property to them with the present intention that they keep it. ${ }^{19}$ On the other hand, if wrongdoers who acquire voidable title are also under an "unconditional" obligation to repay, swindlers and extortioners as well as thieves and embezzlers would escape taxation at the time of misappropriation. The lower courts, in effect, made voidable title the dividing line. Two Tax Court cases, relying on $I$ illcox without discussion, held embezzled funds non-taxable in the year of receipt $;^{20}$ a district court, in dicta, indicated that stolen goods were not taxable when taken. ${ }^{21}$ But the Tax Court, finding that the payers consented to the transfer, held extorted funds taxable in the year of extortion. ${ }^{22}$ And the Fifth Circuit in the Akcrs case taxed swindled money upon receipt because the court thought that a swindler should be estopped from denying his title in order to avoid taxation. ${ }^{23}$

In Rutkin v. United States, ${ }^{24}$ the Supreme Court held extorted funds taxable, but on a rationale that embraced two conflicting criteria for taxing other unlawful gains. The Court, five to four, affirmed a conviction for tax exasion based on the defendant's failure to report extorted funds as income. ${ }^{25}$ Ignor-

17. See Rutkin v. United States, 343 U.S. 130, $139-40$ (1952) (dissenting opinion); United States v. Rutkin, 189 F.2d 431, 441-2 (3d Cir. 1951) (dissenting opinion).

1S. Brown, Law of Personal Property 19-21, $\$ 15$ (1936); Corgey, Law of RePLEVIN $\$ 410$ (2d ed. 1900).

19. Brown, op. cit. supra note $18, \$ 70 ; 2$ Bundick, Trre L.aw of Canse $\$ \$ 535,635$ (1946) ; 3 Williston, Sales of Goons $\$ \$ 625 a, 635$ (1948).

20. George H. Conradson, 5 T.C.M. 112 (1946); Agnes McCue, 5 T.C.Mr. 141 (1946).

21. See United States v. Iozia, 104 F. Supp. S46, S4S (S.D.N.Y. 1952) (proceeds from sale of converted goods tarable).

22. Estate of Joseph Nitto, 13 T.C. $\$ 58$ (1949).

23. Akers v. Scofield, 167 F.2d 71S (5th Cir.), cert. dessicd, 335 U.S. $\$ 23$ (194\$); 37 InL B.J. 92 (1948); is OkLA. ST. B.J. 1752 (1947); 1 VAvo. L. REv. 299 (1948). Prior to Wilcox, courts generally refused to allow taxpayers to raise their wrongful conduct as a bar to taxation. E.g., Johnston v. MícLaughlin, 55 F.2d 1068, 1069 (9th Cir. 1932) ; Commonwealth Investment Co., 44 B.T.A. 445, 451 (1941); James P. McKenna, 1 B.T.A. 326, 328 (1925). Contra: MÍcKnight v. Commissioner, 127 F.2d 572 (5th Cir. 1942).

24. 343 U.S. 130 (1952).

25. Iustice Burton, lone dissenter in Wilcox, wrote the majority opinion. The four dissenters charged that "the Court today adopts the reasoning of his prior dissent, thereby rejecting the IVilcox interpretation of $\$ 22(a)$." Rutkin v. United States, 343 U.S. 130,140 . See note 26 infra.

Neither the majority nor the minority discussed the legal possibility (or impossibility) 
ing the Wilcox rationale, the majority seemed to erect a new test of taxability: "An unlawful gain, as well as a lawful one, constitutes taxable income when its recipient has such control over it that, as a practical matter, he derives readily realizable economic value from it."26 This standard wottld presumably tax all wrongful appropriations, including embezzlements atnd thefts, since a wrongdoer obtains at least temporary "control" over his loot. But the majority refused to overrule Wilcox; they confined the earlier decision to its facts and then distinguished it by noting that an extortioner, unlike an embezzler, obtains funds "from a victim with his consent."27 The Court did not explain the significance of such consent. Yet its only legal consequence is to pass voidable title to the wrongdoer. ${ }^{28}$ In effect, Rutkin did not decide whether control or voidable title will be the measure of taxability, thus leaving uncertain the future tax status of theft and embezzlement.

Application of the "control" criterion to all illegal income would eliminate the unrealistic distinction voidable title makes between different classes of wrongdoers. Embezzlers and thieves enjoy the same economic advantages from their loot as do swindlers and extortioners. True, embezzlers and thieves are theoretically under an immediate duty to repay because they lack title to their ill-gotten gains, ${ }^{29}$ while swindlers and extortioners are not obliged to repay until the rightful owner voids their title. ${ }^{30}$ But in either case the victim may be forced to use the courts to enforce his rights. The only other doctrinal difference between the two classes of wrongdoers lies in their ability to pass good title to third parties. Swindlers and extortioners can pass title to good faith purchasers whose rights to the property will be superior to those of the rightful owner. ${ }^{31}$ On the other hand, embezzlers and thieves can pass good title to third parties only when transferring money and negotiable in-

of proving "wilfulness" in a tax evasion prosecution in which the question of taxability" is decided, five to four, by the Supreme Court. See United States v. Murdock, 290 U.S. 389, 396 (1933).

26. Rutkin v. United States, 343 U.S. 130, 137 (1952). This formulation seems little different from the pre-Wilcox "claim of right" test. See note 13 supra and accompanying text. In fact, to buttress its criterion, the Court quoted from National City Bank v. Helvering, 98 F.2d 93 (2d Cir. 1938), where the Second Circuit advanced perhaps the broadest interpretation of the pre-Wilcox doctrine.

27. Rutkin v. United States, 343 U.S. 130, 138 (1952). See also Estate of Joseph Nitto, 13 T.C. 858, 866-7 (1949).

28. See note 19 supra.

29. See Commissioner v. Wilcox, 327 U.S. 404, 408 (1946).

30. Restatentent, Contracts $\$ \$ 476,495$ (1932); REstatenent, Restitution $\$$ 64, 144 (1937). But unreasonable delay by the victim may defeat his right to avoid title if injury to third parties who relied on the wrongdoer's possession, or inordinate injury to the wrongdoer, would result. REstatensent, Contracts $\$ 483$ (1932); REsTATEvent, RESTITUTION $\$ 64$ (1937). In such a case the victim must seek a money recovery. Id. $\S 144$, comment $b$.

31. Restatement, Restitution $\$ \$ 172,173$ (1937); Uniform SAles ACT $\$ 24 ; 3$ Williston, Sales of Goods $\S 650$ (1948). 
struments. 32 The effect of this inability to pass title to chattels is to permit the rightful owner to recover also from an innocent transferee, ${ }^{33}$ who may then sue the wrongdoer. ${ }^{34}$ To exempt thieves and embezzlers from taxition because they lack this incident of ownership 35 is to ignore the fact that its absence does not affect their liability to the original owner and only occasionally hinders them in disposing of their loot to unlnowing third parties.

The "control" test also avoids the inequities and drawbacks of the delay in the imposition of taxes necessitated by the title standards. Under the Wilco. rationale, voidable title or the absence of title does not exempt misappropriated property from taxation permanently but merely postpones liability until the victim's forgiveness or the running of the statute of limitations bestows good title upon the wrongdoer. ${ }^{37}$ Such a delay accords wrongdoers more favorable tax treatment than honest taxpayers. A law-abiding citizen must

32. Beown, Law of Personal Property $\$ \$ 67,69$ (1936); Untrobsi Nerotingle INSTRUAIENTS LAW $\$ 57$.

33. 1 Restatenient, Torts $\$ 229$ (1934); Brown, Law of Persorial Proferti $\$ 67$ (1936) ; CobBey, LAw of RePLEVIN $\$ 410$ (2d ed. 1900).

34. Restatenent, Restitution $\$ \$ \$ 9,91$ (1937).

35. Individuals, after disposing of most of the incidents of ownership, have been taxed for retaining far less control over income than the wrongloers pussess. E.g., Burnet v. Wells, 289 U.S. 670 (1933) (trust income applied to payment of insurance premiums on settlor's life taxable to settlor); Corliss v. Bowers, 281 U.S. 376 (1930) (incume to settlor's wife from tevocable trust tasable to settlor). Cf. Helvering v. Horst, 311 U.S. 112 (1940) (interest accrued on bond coupons, given to son, taxed to father who retained bonds).

36. Under some circumstances, such as the sale of automobiles, a document of title is necessary to transfer title. See 2 Winsiston, SALEs of Goods $\$ 316$ (1948). Inability to provide the document of title may therefore inhibit sales to those who lnow such papers are required.

37. See text at note 12 suspra. Wilcox spoke of "forgiveness or condonation" by the rightful owner, Commissioner v. Wilcox, 327 U.S. 404, 409-10 (1946), and of "cancellation or retirement" of the indebtedness, id. at 408. The Court of Appeals in Rtut?iss apparently interpreted "condonation" to include inaction by the rightful owner which allowed the statute of limitations to run. United States v. Rutlin, 1S9 F.2d 431, 436 (3d Cir. 1951). However, the court held the funds taxable in the year of receipt rather than in the year the statute ran.

For a general discussion of statutes of limitations on the right to recover property, see Brown, LAw of Persoxal Property $\$ 16$ (1936). When a statute runs, the wrongdoer obtains title which is good against all parties. Ibid.

Extinguishment of an obligation to repay by an act of the creditor may result in the debtor receiving either income or a gift. Compare Commissioner v. Jacobson, 336 U.S. 28 (1949) (forgiveness of debt led to income), with Helvering v. American Dental Co., 318 U.S. 322 (1943) (forgiveness of debt led to gift). But when the statute of limitations extinguishes the duty to repay, the debtor will probably be held to have received income. Securities Co. v. United States, 85 F. Supp. 532 (S.D.N.Y. 1948) (Anicricas: Dental distinguished). Cf. Boston Consol. Gas Co. v. Commissioner, 12S F.2d 473, 475 (1st Cir. 1942) (unclaimed deposits and refunds); Charleston \& W.C. Ky. v. Burnet, 50 F.21 342 (D.C. Cir. 1931) (unclaimed wages); Chicago, R.I. \& P. Ry. v. Commissioner, 47 F.2d 990 (7th Cir. 1931) (unclaimed fare overcharges). 
pay a tax on funds which he receives and treats as his own, even though he later discovers the funds must be repaid. ${ }^{38}$ Such taxpayers forego the opportunity to earn interest on the amount paid in taxes and run the risk that the deduction allowed in the year of repayment may not offset the tax paid in the year of receipt. ${ }^{39}$ The wrongdoer, however, benefits from the use of the money that he would otherwise have paid earlier in taxes and avoids the risk of a possibly useless deduction in the year of repayment. Furthermore, postponed taxation reduces the Government's chances of ever collecting any revenue on illegal income. During the delay the wrongdoer might spend his ill-gotten gains and frustrate taxation by insolvency. ${ }^{40}$ And the difficulty of discovering the extinguishment of his duty to repay would compound the problems of enforcement officers, already burdened with the task of discovering the wrongdoer's acquisition of the funds. ${ }^{41}$ In addition, the exemption of embezzled funds from taxation in the year of receipt might prove helpful to unscrupulous businessmen. Members of partnerships and owners of closely-held corporations might omit from their returns company receipts pocketed with the tacit approval of their associates. When faced with a tax evasion prosecution or a claim for unpaid taxes for the year of receipt, they might choose to resist prosecution or payment with the argument that the money was "embezzled" and thus not taxable in that year. ${ }^{42}$ And, by giving a note to the company for the unreported sum, they could seek to keep alive their "obligation to repay" beyond the statute of limitations on the company's action to recover the

38. See notes 5 and 13 supra.

39. This result has been severely criticized. E.g., Comment, 58 Yale L.J. 955, 955-8 (1949); 35 Iowa L. Rev. 118, 121-2 (1949); Magill, Taxable Incone 209-10 (1945).

Under the "control" test all illegal gains would presumably be taxed upon receipt. If the wrongdoer later repays the rightful owner, he probably will be entitled to a deduction. Payments to private parties for violations of statutes and common law, unlike penalties paid to the government, are generally deductible. See Note, 59 YALE L.J. 561 (1950) ; Helvering v. Hampton, 79 F.2d 358 (9th Cir. 1935) (payment of judgment for fraud deductible). But cf. William F. Davis, Jr., 17 T.C. 549 (1951) (slim majority held payments to corporation required of executive for violating the insider-profit provisions of the Securities Exchange Act non-deductible because (1) considered "penalty," not restitution, and (2) deductibility would frustrate statutory enforcement).

40. See 2 Mertens, The Law of Federal Incone Taxation $\$ 12.103$ n.74 (1942).

41. Where property is taken covertly or obtained by fratud, the statute of limitations on the victim's right of recovery does not begin to run until the loss or fratud is discovered or should have been discovered. To expect taxing authorities to determine when the statutory period begins and ends in such situations is to demand the impossible. $C$. Walter J. Cutcliffe, 5 T.C.M. 673, 675 (1946).

42. See United States v. A. Augustine, 188 F.2d 359 (3d Cir. 1951); United States v. Chapman, 168 F.2d 997 (7th Cir.), cert. denied, 335 U.S. 853 (1948); Currier v. United States, 166 F.2d 346 (1st Cir. 1948) ; W. L. Kann, 18 T.C. No. 131 (1952) ; Louis C. Buff Estate, 4 T.C.M. 1130 (1945).

Similarly, if the partners or officers are prosecuted for failure to include the "cmbezzled" receipts in the company's income, they might defend by arguing either that the company had never received the funds or that the omission was harmless because the company was entitled to a theft deduction. See Currier v. United States, supra. 
funds." If the "embezzler" later "repays" the firm, he will have had the use of the money without ever having incurred tax liability. If he decides to retain the funds, he may keep alive his obligation to repay indefinitely by periodically renewing the note, or may have the company "forgive" the "debt" in a year of low tax rates or when his income is small. In reported cases, such fatuous arguments have failed because of the transparency of the pretended misappropriations: claims of embezzlement have been rejected where the alleged wrongdoers were the sole owners of a business $;^{14}$ also where majority stockholders, after an audit disclosed a "misappropriation" by minority shareholders active in a family corporation, made little or no effort to prosecute or seek repayment. ${ }^{45}$ Nonetheless, the availability of the "embezzlement" argument provides a convenient strav for taxpayers to clutch in otherwise hopeless litigation.

These defects seem to outweigh the policy arguments in favor of delayed taxation. In Wilcox the Supreme Court apparently sought to protect the rightful owner's ability to recover from the wrongdoer ${ }^{40}$ by postponing the latter's tax liability for the misappropriation until the rightful owner renounced his rights or the statute of limitations barred his recovery. If taves accrue at the time of misappropriation and are paid promptly, the assets leit in the wrongdoer's hands may prove insufficient to satisfy the rightiul owner's claim. When the tares are not paid and the wrongdoer's assets cannot satisfy the claims of both the Government and the victim, a tax lien may accord the Government rights to the assets superior to those of the rightiul owner.ti

43. Cf. W. L. Kann, 1S T.C. No. 131 (1952). The company's acceptance of a note from an "embezzling" partner or officer would prevent him from justifying, with the arguments indicated in note 42 stpra, the failure to include the "cmbezzled" receipts in the company's income.

44. Currier v. United States, 166 F.2d 346 (1st Cir. 1948) (owner of one-man corporation); Louis C. Buff Estate, \& T.C.M. 1130 (1945) (same, pre-l/'ilicus); United States v. A. Augustine, 18S F.2d 359 (3d Cir. 1951) (both partners in two-man partnership). Cf. United States v. Chapman, 16S F.2d 997 (7th Cir.), cort. denicd, 335 U.S. 853 (1948) (defendant, who was president and principal shareholder, held liable for tases on over-ceiling price payments which he received personally and failed to transfer to the corporation). For general discussion, see Rothwacks, Taxability of Corporate Reccipts Dižerted by Officer-Stockholder, 7 N.Y.U. INst. FEn. TAx. 573 (1949).

45. W. L. Kann, 18 T.C. No. 131 (1952).

46. Commissioner v. Wilcos, 327 U.S. 404, 410 (1946). See also MfeKnight v. Commissioner, 127 F.2d 572, 574 (5th Cir. 1942).

47. As to property subject to tax liens, see INT. Rer. Cove $\$ 3670$. Section 3671 provides that the lien shall arise upon receipt of the assessment list by the collector. Unless a jeopardy assessment is made, there will be no assessment until the taspayer has been notified of the deficiency and fails to pay, or, if he contests his liability, until a desisiun against him by the Tax Court. Section 3672 provides that the tas lien shall not be valid as against mortgagees, pledgees, purchasers, or judgment creditors until recurded as therein provided. See generally, 9 Jertens, The LAW wF Fengul I::Cous Tasatio: $\$ \$$ 54.38-54.51 (1943, Supp. 1952) ; Clark, Federal Tax Licus and Their Euforcemen!, 33 VA. L. REv. 13 (1947). 
And if the wrongdoer enters either state insolvency or federal bankruptcy proceedings, tax claims based on the misappropriation will receive priority in the distribution of his assets. ${ }^{48}$ In each instance, the Government may frustrate, in whole or in part, the rightful owner's recovery. However, as a practical matter, it seems likely that in many cases the victim will locate the wrongdoer and recover, or at least obtain a lien, before the Government asserts its tax claim. And a victim who does recover or acquire a lien before dissipation of the wrongdoer's assets or before the Government's lien arises will obviously not be harmed by the fact that the wrongdoer incurs tax liability at the time of misappropriation. Moreover, even where a tax lien has arisen or the wrongdoer has entered insolvency or bankruptcy proceedings before the victim asserts his rights, the victim can recover identifiable property or traceable proceeds before payment of tax claims. ${ }^{40}$ In other cases, insurance may compensate for, or a tax deduction may mitigate, the victim's loss. ${ }^{50}$ In any event,

48. The Government can obtain a tax lien under INT. Rev. CoDE $\$ \$ 3670-2$ or rely on its statutory priority under REv. STAT. §3466 (1875), 31 U.S.C. $\$ 191$ (1946), which reads: "Whenever any person . . . is insolvent, ... debts due to the United States shall be first satisfied. ..." Such debts include taxes owed the United States. Price v. United States, 269 U.S. 492 (1926).

In state insolvency proceedings the Government, even without a lien, may use $\$ 3466$ in order to come before the rightful owner. In dicta, the Supreme Court has long indicated that the Government's priority might be defeated by a "specific and perfected lien upon the property at the time of insolvency." See United States v. Waddill, Holland \& Flinn, Inc., 323 U.S. 353, 355 (1945). But in no case has the Court held a non-consensual lien sufficiently "specific and perfected" to defeat the Government's priority. Ilid.; Thelusson v. Smith, 2 Wheat. 396, 425 (U.S. 1817) (statute makes no exception in favor of judgment creditors).

In federal bankruptcy proceedings, $\S 64 a$ of the Bankruptcy Act of 1938, as amended, 11 U.S.C. $\$ 104 a$ (Supp. 1952), reduces unsecured tax claims to a fourth priority, while $\$ 3466$ claims receive a fifth priority. Hence, if the victim acquires a lien he will take before the Government unless the Government has also obtained a lien which is prior in time.

See generally 3 CoLlier, BANKruptcy $\S 64.403$ (14th ed., Moore, 1941, Supp. 1951); 4 id. $\$ \$ 67.20,67.24$ (1942, Supp. 1950) ; 9 Mertens, The Law of Federnd Incone TAXation $\$ \$ 54.10-54.37$ (1943, Supp. 1952).

49. 3 CoLLIER, op. cit. supra note $48, \S \S 60.18,60.24 ; 4$ id. $\S \S 70.25,70.41$. But where the rightful owner must first void the insolvent's title in order to obtain such recovery, failure to do so will reduce him to the status of a general creditor. 3 id. $\$ 60.18$.

50. INT. Rev. CoDE $\$ \S 23(\mathrm{e})$ and $23(\mathrm{f})$ permit deductions for losses from theft or embezzlement in the "year in which sustained." U.S. Treas. Reg. 111, \$29.43-2 (1943). But such losses can be deducted only to the extent not compensated by insurance. Sce cases discussed in Geller \& Rogers, Embezzlement Has Its Tax Problems, Too, 26 TAxes 1097, 1103-4 (1948). Courts disagreed, however, over the year in which such deductions could be taken. Compare First Nat. Bank of Sharon v. Heiner, 66 F.2d 925 (3d Cir. 1933) (year misappropriation occurred), with Boston Consol. Gas Co. v. Commissionter, 128 F.2d 473, 476 (1st Cir. 1942) (year of discovery). Recently the Supreme Court resolved this conflict by allowing deduction of embezzlement losses in the year of discovery. Alison v. United States, 344 U.S. 167 (1952). To limit such deductions to 
the desire to prevent occasional losses to innocent victims falls short of justifying postponement of taxation on all thefts and embezzlements. ${ }^{51}$

The four Rutkin dissenters opposed the inclusion of misappropriated funds in taxable income on the policy ground that tax evasion prosecutions may be used to punish the wrongdoer for the misappropriation itself, thereby permitting the Federal Government to encroach upon the functions of local law enforcement officers. ${ }^{52}$ If the minority intended to follow $I F i l c o x$ and merely delay taxation, ${ }^{53}$ the alleged evil would still be present in those cases where the wrongdoer does not repay his victim and fails to include the misappropriated property in his taxable income for the year in which his duty to repay is extinguished. Thus it seems more likely that the dissenters would permanently exempt misappropriations from taxation. But the minority did not question the taxability of profits of illegal businesses, such as gambling and bootlegging. To justify the difference in treatment, they assumed that misappropriations are "sporadic," in contrast to the "regular profits" of illegal enterprises." In view of recent revelations of organized extortion, thieving, and swindling, this assumption seems erroneous. ${ }^{\text {to }}$ Yet even if there is a factual distinction

the year of misappropriation would be unduly harsh on taspayers since embezzlements often remain undiscovered for many years. Id. at 192. For example, the aversge period of concealment of bank embezzlements is ten to eleven years. N.Y. Times, Des 7, 1952, $\S 3$, p. 6 , col. 4 .

Losses from swindling and extortion can be deducted as business expenses if "ordinary and necessary." INT. REv. CoDE $\$ 23(a)$. To meet this test, expenses probably must be both customary and not violative of express public policy. Reliable Mfills \& Cream Co, Inc, 1938 P-H B.T.A. Memo. I 38,290 (extortion payments by mill dealers not "ordinary and necessary" because illegal). Butr cf. Marra Bros., Inc., 3 T.C.Mr. 1317 (1944) ("tips" paid ship's officers by stevedoring firm to avoid noncooperation held deductible beeause "ordinary and necessary"). In this context, public policy has been defined as "national or state policies evidenced by some governmental declaration. . . ." Lilly v. Commissioner, 343 U.S. 90, 97 (1952) (opticians' kickbacks to prescribing oculists dedurtible although violative of professional ethics). For the non-business taxpayer, swindling and extortion losses might be deductible as theft losses. See Samuel M. Felton, 5 T.C. 256 (1945) (losses in Ponzi-type investment swindle deductible as "embezzlement" losses).

If an insurance company compensates the victim, it normally will be subrogated to his rights against the wrongdoer. VANCE, LAw of INSURANCE $\$ 134$ (3d ed. 1951).

51. Mr. Justice Burton has suggested a statutory amendment to deny the Government a priority over a victim where the Governmont's tax claim arises out of the misappropriation. See Commissioner v. Wilcox, 327 U.S. 404, 414 (1946) (dissenting opinion).

52. United States v. Ruthin, 343 U.S. 130, 141-7 (1952).

53. See notes 12 and 37 stpra and accompanying text.

54. United States v. Rutkin, 343 U.S. 130, 141 (1952).

55. See, generally, the disclosures of the Kefauver Committee, SER. REP. NOS. 141, 307,725 , 82d Cong., 1st Sess. (1951), and the New Yorl Crime Commission, 21. Y. Times, circa Dec. 1952-Jan. 1953; Hall, TheFt, Law aNd Soctety 155-64, 250-6 (2. ed. 1952). Similarly, bootlegging and gambling may be conducted on a sporadic basis. In any event, a tax on illegal income because of its regularity seems inconsistent with general tax polic:. For example, gains of a single wager are taxed just as are regular profits of a professional gambler. A. L. Voyer, 4 B.T.A. 1192 (1926) (lottery winnings). 
between the "regularity" of, for example, gambling as opposed to extortion, the relevancy of "regularity" to taxability is questionable-particularly since the dangers of federal punishment for local crimes would remain in tax evasion prosecutions of gamblers. ${ }^{.6}$ In any event, the encroachment argument misses the essential point that the state and federal prosecutions are based on separate acts. A prosecution for tax evasion is not a necessary consequence of a profitable violation of local law ; the criminal must also fail to report as income the fruits of that crime. The dissenters were obviously aware of this. Their real fear, therefore, seems to have been the possibility that evidence of the illegal origins of a taxpayer's income will prejudice his case. ${ }^{.7} \Lambda$ gain, this possibility also exists when the defendant is engaged in a "regular" illegal business. The danger of prejudice should be met through extreme catution by the trial judge in his conduct of the trial rather than by granting tax benefits to one class of wrongdoers. To exempt misappropriators from taxation because of the possible abuse in tax evasion prosecutions which might be brought if they fail to report illegal income seems grossly tunfair to honest citizens, who must bear the usual burdens of taxation. ${ }^{68}$

56. For a list of prominent underworld entrepreneurs convicted of tax evasion, see Baker, Taxation: Potential Destroyer of Crime, 29 CHI-KENT Rev. 197, 200 n.3 (1951). The recent imposition of a wagering tax, INT. REv. CoDE $\$ \S 3285-98$, reveals a congressional intent to use the taxing power as a positive weapon against criminals. The dissenters did not discuss this index of congressional intent.

57. Rutkin v. United States, 343 U.S. 130, $145-7$ (1952). See United States v. Caserta, 199 F.2d 905 (3d Cir. 1952) (in tax evasion prosecution based on net worth theory, Government permitted to show certain payments by taxpayer were fines imposed for violations of local law).

58. See United States v. Sullivan, 274 U.S. 259, 263 (1927). The Rutkin dissenters sought to avoid the "unfairness" objection by arguing that the cost of collecting taxes on misappropriations would be greater than the revenue obtained. Rutkin v. United States, 343 U.S. 130, 141 (1952). There is substantial evidence to the contrary. Misappropriations mount up to sizable sums annually. For example, the annual total of embezzlements has been estimated at $\$ 400,000,000$. Peterson, Why Honest Pcople Stcal, 38 J. CRIMr. LAW \& CrIminology 94 (1947). Moreover, misappropriations are not limited to isolated acts of small-time amateurs but also form a lucrative saurce of income for organized crime syndicates. See sources cited in note 55 supra. Furthermore, collection of revenue on illegal income generally has thus far more than paid its way. Following the recommendations of the Kefauver Committee, SEN. Rep. No. 141, 82d Cong., 1st Sess. 34 (1951), the Treasury Department assigned a special "racket squad" to examine the income tax returns of criminals. Despite the difficulties inherent in building a successful case where it is hard to obtain witnesses to specific receipts and where the taxpayer usually keeps few records, the "racket squad," operating on a $\$ 15,000,000$ budget, collected $\$ 95,000,000$ in additional taxes and penalties in its first year of operation. Lader, A New Way to Wipe Out Rackets, N.Y. Herald Tribune, Dec. 7, 1952, §7, p. 7. These statistics do not show the amount of taxes paid on illegal income without resort to enforcement. The fear of a tax evasion conviction has apparently led many criminals to report such gains. Baker, Taxation: Potential Destroyer of Crime, 29 Cur-Kent Rev. 197, 216 (1951). 